\title{
Poziom dochodów a konsumpcja polskich gospodarstw domowych w latach 2007-2013 w świetle badań statystycznych
}

\author{
Autor: Katarzyna Kachel
}

\begin{abstract}
Abstrakt
W artykule wskazano najważniejsze zmiany i tendencje w poziomie oraz strukturze dochodów i wydatków gospodarstw domowych w Polsce. W pracy została postawiona teza, mówiąca o tym, że przemiany struktury wydatków w polskich gospodarstwach domowych w latach 2007-2013 to jeden z wielu czynników, który wpływa na kształtowanie kondycji finansowej tych gospodarstw, a także wraz z innymi determinantami wpływa na upowszechnienie się wzorców konsumpcji wśród ludności. Analizie poddano ogół gospodarstw domowych w Polsce od 2007 do 2013 r. W badaniu wykorzystano dane pochodzące z Głównego Urzędu Statystycznego oraz opracowania Budżety gospodarstw domowych i Sytuacja gospodarstw domowych w świetle wyników badań budżetów gospodarstw domowych. Na podstawie przeprowadzonej analizy wskazano, że zmiany w strukturze dochodów oraz wydatków gospodarstw domowych w Polsce mogą być jednym z wielu czynników wpływających na kształtowanie się kondycji ekonomicznej członków tych gospodarstw.
\end{abstract}

Słowa kluczowe: gospodarstwa domowe, dochód rozporządzalny, wydat$\mathrm{ki}$, budżet gospodarstwa domowego, elastyczność cenowa popytu, dobra podstawowe, dobra wyższego rzędu,

\section{Wstęp}

W wyniku rozwoju gospodarki rynkowej zmienił się sposób funkcjonowania nie tylko przedsiębiorstw, ale i gospodarstw domowych. Działalność tych podmiotów nastawiona jest konsument

JEL: D12

Historia: otrzymano 2015-10- 30, poprawiono 2016-03-02, zaakceptowano 2016-03- 14

przede wszystkim na zaspokojenie potrzeb konsumpcyjnych, których struktura podlega nieustannym zmianom. Podstawowym czynnikiem ekonomicznym, który determinuje poziom konsumpcji, są dochody gospodarstw domowych. Ich wysokość czy struktura 
stanowi istotny element analizy poziomu i proporcji wydatków ludności. Wydatki poniesione na zakup dóbr i usług konsumpcyjnych są uzależnione przede wszystkim od poziomu dochodów nominalnych, cen oraz wielkości podaży. Do dochodów nominalnym zalicza się: wynagrodzenia za pracę, pieniężne świadczenia społeczne $\mathrm{i}$ inne dochody osobiste, m.in. spożycie naturalne oraz dochody uzyskiwane ze świadczeń społecznych $w$ naturze. Dochody nominalne nie mają dużego znaczenia w przypadku wydatków przeznaczonych na zakup artykułów żywnościowych, tak jak ma to miejsce w przypadku niektórych artykułów nieżywnościowych. Dlatego też $\mathrm{w}$ takiej sytuacji istotną rolę odgrywają dochody realne, tj. dochody pieniężne i dochody w naturze skorygowane o zmiany cen (Urban, Szlachta 1995: 191).

Poziom i struktura wydatków są w głównej mierze determinowane przez sytuację materialną, ale również wpływ na nie ma skład gospodarstwa domowego, status na rynku pracy, a także stan zdrowia jego członków. Możliwości pozyskiwania dochodów, gromadzenia oszczędności oraz zaciągania zobowiązań $w$ różnym stopniu wpływają na dostęp do dóbr i usług oraz przekładają się na jakość życia. Ograniczenia dochodowe nie tylko wpływają na poziom i dynamikę konsumpcji, ale również na możliwości i sposoby radzenia sobie $w$ różnych sytuacjach. Wzrost dochodu wpływa nie tylko na zwiększenie popytu na dobra i usługi, lecz także powoduje zmianę struktury wydatków polegającą na zwiększeniu w ogólnych wydatkach konsumentów wydatków na zakup dóbr wyższego rzędu, a zmniejszeniu wydatków na zakup dóbr niższego rzędu.

Celem niniejszego artykułu jest ocena sytuacji materialnej polskich gospodarstw domowych w ujęciu czasowym (za lata 2007-2013) w świetle takich kategorii ekonomicznych, jak przeciętne miesięczne dochody i wydatki osiągane przez gospodarstwa. Kolejny, poznawczy cel artykułu stanowi analiza skali i poziomu zróżnicowania tych kategorii w zależności od typu gospodarstwa domowego. Istotna staje się odpowiedź na pytanie o obiektywny poziom dochodów i wydatków, a także określenie relacji między tymi wielkościami w każdej grupie gospodarstw domowych. W pracy założono tezę, że przemiany struktury wydatków w polskich gospodarstwach domowych w latach 20072013 to jeden z wielu czynników, który wpływa na kształtowanie kondycji finansowej tych gospodarstw, a także wraz z innymi determinantami wpływa na upowszechnienie się wzorców konsumpcji wśród ludności. Przedmiotem analizy jest ogół gospodarstw domowych w Polsce od 2007 do 2013 r. W badaniu wykorzystano dane pochodzące z Głównego Urzędu Statystycznego oraz opracowania Budżety gospodarstw domowych i Sytuacja gospodarstw domowych w świetle wyników badań budżetów gospodarstw domowych.

\section{Dochody polskich gospodarstw domowych}

Dochody stanowią najważniejszy czynnik determinujący strukturę wydatków gospodarstw domowych. Ich poziom i struktura przyczyniają się do realizacji potrzeb według ustalonej hierarchii, gdyż wysokość dochodów determinuje sytuację materialną członków gospodarstwa domowego, a zarazem kształtuje poziom i jakość życia całej rodziny (Włodarczyk-Śpiewak 2007: 65-66). Dochody gospodarstw domowych określane są przez sumę przychodów z tytułu pracy zarobkowej lub świadczeń społecznych, oszczędności i różnego rodzaju dochodów z kapitału, a także zasoby materialne, tj.: nieruchomości, dzieła sztuki, 
artykuły trwałego użytku, pomniejszone o obciążenia finansowe. Wiele reakcji zakupowych konsumentów wynika ze zmian dochodów członków gospodarstwa domowego. Wzrostowi dochodów z reguły będzie towarzyszyć wzrost zakupów, natomiast spadkowi - ograniczenie zakupów. Sposób i intensywność, w jakich gospodarstwa reagują na wyżej wymienione zmiany, można określić na podstawie elastyczności dochodowej popytu (Kopycińska 2005: 69). W wielu przypadkach intensywne reakcje konsumentów na zmianę dochodów widoczne są w odniesieniu do dóbr wyższego rzędu, zwłaszcza do towarów trwałego użytku.

Dochód rozporządzalny jako kategoria w badaniach nad budżetami gospodarstw domowych to suma bieżących dochodów tych gospodarstw z różnych źródeł pomniejszona o zaliczki na podatek dochodowy od osób fizycznych (płacone przez płatnika w imieniu podatnika), o podatki od dochodów i własności płacone przez osoby pracujące na własny rachunek oraz o składki na ubezpieczenia społeczne i zdrowotne. Dochód rozporządzalny przeznaczony jest na wydatki oraz przyrost oszczędności (Piekut 2008: 35-36). Wielkość przeciętnego miesięcznego dochodu rozporządzalnego gospodarstw domowych w przeliczeniu na jedną osobę jest jednym z najistotniejszych determinantów kształtujących poziom i strukturę konsumpcji w gospodarstwach domowych. Jest również syntetycznym miernikiem poziomu życia ludności, zwłaszcza przy określaniu różnic między grupami wyodrębnionymi, np. ze względu na liczbę osób w gospodarstwie domowym, fazę cyklu rozwoju rodziny czy też grupę społeczno-ekonomiczną.

Tabela 1 przedstawia przeciętne miesięczne dochody polskich gospodarstw domowych ogółem oraz w poszczególnych grupach społeczno-ekonomicznych w latach 2007-2013. Natomiast w tabeli 2 przedstawiono dynamikę zmian dochodów w poszczególnych grupach gospodarstw domowych w Polsce.

$\mathrm{Na}$ podstawie tabel 1 i 2 można stwierdzić, że w latach 2007-2013 odnotowano systematyczny wzrost przeciętnych miesięcznych dochodów

Tabela 1. Przeciętne miesięczne dochody rozporządzalne na 1 osobę $w$ gospodarstwach domowych w Polsce wyrażone w cenach stałych (w zł)

\begin{tabular}{|c|c|c|c|c|c|c|c|}
\hline $\begin{array}{c}\text { Gospodarstwa } \\
\text { domowe }\end{array}$ & $\mathbf{2 0 0 7}$ & $\mathbf{2 0 0 8}$ & $\mathbf{2 0 0 9}$ & $\mathbf{2 0 1 0}$ & $\mathbf{2 0 1 1}$ & $\mathbf{2 0 1 2}$ & $\mathbf{2 0 1 3}$ \\
\hline Ogółem & 928,87 & 1045,52 & 1114,49 & 1192,82 & 1226,95 & 1278,43 & 1299,07 \\
\hline Pracowników & 915,17 & 1049,84 & 1123,30 & 1199,22 & 1243,84 & 1289,16 & 1305,87 \\
\hline Rolników & 846,76 & 887,35 & 884,01 & 1024,53 & 983,88 & 1091,55 & 1156,13 \\
\hline $\begin{array}{c}\text { Pracujących na } \\
\text { własny rachunek }\end{array}$ & 1251,07 & 1338,51 & 1396,47 & 1468,38 & 1497,43 & 1536,68 & 1581,05 \\
\hline $\begin{array}{c}\text { Emerytów i ren- } \\
\text { cistów }\end{array}$ & 937,63 & 1031,94 & 1116,30 & 1180,82 & 1233,08 & 1297,90 & 1328,65 \\
\hline
\end{tabular}

Źródło: Rocznik Statystyczny 2008, Warszawa, GUS., s. 190; Sytuacja gospodarstw domowych w 2008 r. w świetle wyników badania budżetów gospodarstw domowych, Warszawa, GUS., s. 17; Sytuacja gospodarstw domowych w 2009 r. w świetle wyników badania budżetów gospodarstw domowych, Warszawa, GUS., s. 17; Rocznik Statystyczny 2011, Warszawa, GUS., s. 195; Sytuacja gospodarstw domowych w 2011 r. w świetle wyników badania budżetów gospodarstw domowych, Warszawa, GUS., s. 21, Rocznik Statystyczny 2014, Warszawa, GUS., s. 299. 
Tabela 2. Dynamika zmian przeciętnym miesięcznych dochodów rozporządzalnych w poszczególnych grupach gospodarstw domowych w latach 2007-2013 (w \%)

\begin{tabular}{|c|c|c|c|c|c|c|c|}
\hline \multicolumn{7}{|c|}{ Dynamika $\mathbf{2 0 0 7}=\mathbf{1 0 0 \%}$ (w\%) } \\
\hline Lata & $\mathbf{2 0 0 7}$ & $\mathbf{2 0 0 8}$ & $\mathbf{2 0 0 9}$ & $\mathbf{2 0 1 0}$ & $\mathbf{2 0 1 1}$ & $\mathbf{2 0 1 2}$ & $\mathbf{2 0 1 3}$ \\
\hline $\begin{array}{c}\text { Gospodarstwa } \\
\text { domowe ogółem }\end{array}$ & 100,0 & 112,6 & 120,0 & 128,4 & 132,1 & 137,6 & 139,9 \\
\hline Pracowników & 100,0 & 114,7 & 122,7 & 131,0 & 135,9 & 140,9 & 142,7 \\
\hline Rolników & 100,0 & 104,8 & 104,4 & 121,0 & 116,2 & 128,9 & 136,5 \\
\hline $\begin{array}{c}\text { Pracujących na } \\
\text { własny rachunek }\end{array}$ & 100,0 & 107,0 & 111,6 & 117,4 & 119,7 & 122,8 & 126,4 \\
\hline $\begin{array}{c}\text { Emerytów i ren- } \\
\text { cistów }\end{array}$ & 100,0 & 110,1 & 119,1 & 125,9 & 131,5 & 138,4 & 141,7 \\
\hline
\end{tabular}

Źródło: opracowanie własne na podstawie danych GUS.

rozporządzalnych na 1 osobę. W ciągu ostatnich siedmiu lat dochody gospodarstw domowych w Polsce wzrosły o 39,9\%. Największą dynamikę wzrostu dochodów wykazano w gospodarstwach domowych pracowników (wzrost o 42,7\%), podobną dynamikę można zauważyć w gospodarstwach domowych emerytów i rencistów (wzrost o 41,7\%). Najmniejszą dynamiką zmian charakteryzowały się przeciętne miesięczne dochody rozporządzalne na 1 osobę w gospodarstwach domowych pracujących na własny rachunek (wzrost o 26,4\%). Gospodarstwa domowe pracowników, które cechowały się najwyższymi zmianami w dochodach, odnotowały dochody niższe w porównaniu z danymi liczonymi dla ogółu polskich gospodarstw tylko w pierwszym roku badania. W pozostałych latach (2008-2013) dochody te były wyższe od dochodów ogółem. W przypadku gospodarstw domowych rolników dochód ten był zawsze niższy od dochodów ogółem, natomiast gospodarstwa domowe osób pracujących na własny rachunek osiągały dochód znacznie przewyższający dochód liczony dla ogółu polskich gospodarstw domowych. Wszystkie grupy społeczno-zawodowe gospodarstw domowych odnotowały w badanym okresie wzrost dochodów. Najlepszą sytuację materialną miały gospodarstwa domowe pracujących na własny rachunek, najsłabszą kondycję ekonomiczną pod względem dochodów wykazywały gospodarstwa domowe rolników. Dochody gospodarstw domowych rolników charakteryzowały się relatywnie dużą zmiennością w czasie. Ich dochody w 2008 roku wzrosły w stosunku do 2007, w kolejnym spadły, a następnie wykazały wzrost o $15,9 \%$. W roku 2011 dochody te ponownie spadły o 4\%, a w kolejnych okresach wykazały niewielki wzrost rok do roku. Wartości przeciętnych miesięcznych dochodów rozporządzalnych na 1 osobę w gospodarstwach domowych w Polsce w badanym okresie zaprezentowano $w$ formie graficznej na wykresie 1 .

Zarysowane zmiany w poziomie przeciętnych miesięcznych dochodów badanej zbiorowości gospodarstw domowych $w$ niejednakowym stopniu ujawniły się w poszczególnych typach tych gospodarstw. Dynamika dochodów w poszczególnych grupach była wyraźnie zróżnicowana. Na podstawie wykresu 1 można zauważyć, że w badanym okresie dochody osób pracujących na własny rachunek przewyższały 


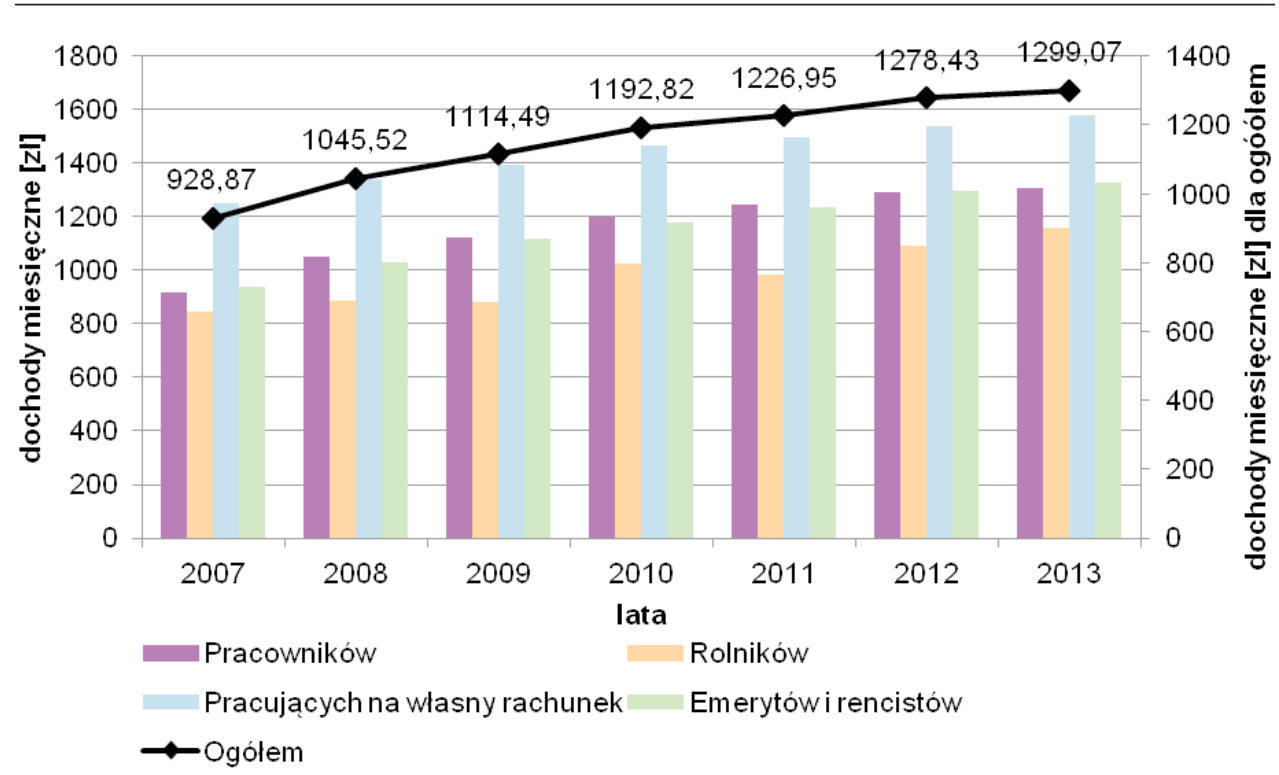

Wykres 1. Kształtowanie się przeciętnych miesięcznych dochodów rozporządzalnych na 1 osobę w gospodarstwach domowych w Polsce w latach 2007-2013

Źródło: opracowanie własne na podstawie danych źródłowych GUS z badań budżetów gospodarstw domowych w Polsce w latach 2007-2013.

dochody ogółem, natomiast przeciętne dochody rozporządzalne pracowników oraz emerytów i rencistów kształtowały się na podobnym do dochodów ogółem poziomie. W najmniej korzystnej sytuacji finansowej znalazły się gospodarstwa domowe rolników. Poziom dochodów tej grupy był niższy od przeciętnego poziomu dochodów całej zbiorowości gospodarstw domowych na przestrzeni badanego okresu. Można stwierdzić, że o ile dawniej (przed reformami ustrojowymi) sektor chłopski był największą enklawą prywatnej działalności gospodarczej w Polsce, o tyle obecnie wyraźnie utracił tę pozycję na rzecz innych grup społeczno-zawodowych.

$\mathrm{Na}$ utrzymanie tendencji wzrostowej dochodów gospodarstw domowych w Polsce w badanym okresie wpływ ma kilka zjawisk, które zauważono w skali całej gospodarki. Przede wszystkim obniżeniu uległa stopa bezrobocia, wzrosło przeciętne miesięczne wynagrodzenie brutto w sektorze przedsiębiorstw, zwiększyła się siła nabywcza płac (w szczególności w odniesieniu do towarów żywnościowych, odzieży i obuwia, łączności, rekreacji i kultury, wyposażenia mieszkań, transportu zdrowia, edukacji). Wzrosła również wysokość przeciętnych emerytur i rent brutto.

Wydatki gospodarstw domowych w Polsce w latach 2007-2013

W ostatnim dziesięcioleciu nastąpiły znaczne zmiany we wzorcach konsumpcji na całym świecie, które doprowadziły do przeobrażeń w zachowaniach konsumentów. Wśród procesów tych należy wymienić przede wszystkim: globalizację, wzrost gospodarczy, 
rozwój technologii, w tym Internetu, spadek przeciętnej wielkości gospodarstw domowych, starzenie się społeczeństwa. W przypadku Polski zmiany w zachowaniach konsumpcyjnych gospodarstw domowych należy rozpatrywać w szerszym kontekście transformacji gospodarczej. Mianowicie, w latach 90. Polska stała się wielkim rynkiem konsumpcyjnym z rosnącym tempem spożycia i dochodów realnych. Gwałtowne powiększenie stanu posiadania gospodarstw domowych w dobra trwałego użytku jest najłatwiejszym sposobem zbliżania się do wzorców konsumpcji obserwowanych w krajach rozwiniętych.

Jednym z mierników oceny funkcjonowania rynku jest poziom i struktura wydatków konsumpcyjnych gospodarstw domowych. Wydatki te są istotnym czynnikiem wskazującym na wielkości i jakość zaspokojenia potrzeb, jak i na różnice w skali i poziomie rozdysponowania dochodów. To w gospodarstwach domowych, czyli najpowszechniejszych i najważniejszych podmiotach gospodarujących sprawdza się efektywność polityki społeczno-gospodarczej kraju. Poziom wydatków, ich ukierunkowanie na zakup określonych grup towarów pozwala zauważyć zarówno podobieństwo, jak i różnice w poziomie życia poszczególnych typów gospodarstw domowych oraz ocenić poziom życia całego społeczeństwa (Kieżel 2004: 73-74).

Zmiany w dochodach powodują konieczność dostosowania budżetów domowych do nowych warunków społeczno-gospodarczych, co wpływa na zmiany w wydatkach gospodarstw domowych. Poziom i struktura wydatków konsumpcyjnych gospodarstw domowych jest również odzwierciedleniem zróżnicowanych wzorców konsumpcji na poszczególnych rynkach. Zróżnicowane wzorce spożycia z kolei odzwierciedlają wielkości konsumpcji różnych dóbr (Świecka 2008: 64). Tabela 3 przedstawia przeciętne miesięczne wydatki polskich gospodarstw domowych ogółem oraz w poszczególnych grupach społeczno-zawodowych w latach 2007-2013. Wydatki zostały wyrażone w cenach stałych. Natomiast w tabeli 4 zaprezentowano dynamikę zmian przeciętnych miesięcznych wydatków rozporządzalnych w poszczególnych grupach gospodarstw domowych.

Tabela 3. Przeciętne miesięczne wydatki na 1 osobę w gospodarstwach domowych według grup społeczno-zawodowych w latach 2007-2013 (w zł)

\begin{tabular}{|c|c|c|c|c|c|c|c|}
\hline $\begin{array}{c}\text { Gospodarstwa } \\
\text { domowe }\end{array}$ & $\mathbf{2 0 0 7}$ & $\mathbf{2 0 0 8}$ & $\mathbf{2 0 0 9}$ & $\mathbf{2 0 1 0}$ & $\mathbf{2 0 1 1}$ & $\mathbf{2 0 1 2}$ & $\mathbf{2 0 1 3}$ \\
\hline Ogółem & 809,95 & 904,27 & 956,68 & 991,44 & 1015,12 & 1058,91 & 1061,70 \\
\hline Pracowników & 791,30 & 887,03 & 941,53 & 979,05 & 1006,05 & 1047,25 & 1050,32 \\
\hline Rolników & 614,96 & 693,57 & 712,00 & 757,25 & 736,02 & 786,57 & 784,62 \\
\hline $\begin{array}{c}\text { Pracujących na } \\
\text { własny rachunek }\end{array}$ & 1093,81 & 1193,00 & 1208,08 & 1206,91 & 1221,52 & 1281,80 & 1288,31 \\
\hline $\begin{array}{c}\text { Emerytów i ren- } \\
\text { cistów }\end{array}$ & 848,26 & 935,31 & 1002,98 & 1041,46 & 1080,14 & 1127,28 & 1144,22 \\
\hline
\end{tabular}

Źródło: Rocznik Statystyczny 2008, Warszawa, GUS., s. 192; Sytuacja gospodarstw domowych w 2008 r. w świetle wyników badania budżetów gospodarstw domowych, Warszawa, GUS., s. 19; Sytuacja gospodarstw domowych w 2009 r. w świetle wyników badania budżetów gospodarstw domowych, Warszawa, GUS., s. 19; Rocznik Statystyczny 2011, Warszawa, GUS., s. 196; Sytuacja gospodarstw domowych w 2011 r. w świetle wyników badania budżetów gospodarstw domowych, Warszawa, GUS., s. 23, Rocznik Statystyczny 2014, Warszawa, GUS., s. 303. 
Tabela 4. Dynamika zmian przeciętnych miesięcznych wydatków rozporządzalnych w poszczególnych grupach gospodarstw domowych w latach 2007-2013 (w \%)

\begin{tabular}{|c|c|c|c|c|c|c|c|}
\hline \multicolumn{7}{|c|}{ Dynamika $\mathbf{2 0 0 7}=\mathbf{1 0 0} \%$ (w \%) } \\
\hline Lata & $\mathbf{2 0 0 7}$ & $\mathbf{2 0 0 8}$ & $\mathbf{2 0 0 9}$ & $\mathbf{2 0 1 0}$ & $\mathbf{2 0 1 1}$ & $\mathbf{2 0 1 2}$ & $\mathbf{2 0 1 3}$ \\
\hline $\begin{array}{c}\text { Gospodarstwa } \\
\text { domowe ogółem }\end{array}$ & 100,0 & 111,6 & 118,1 & 122,4 & 125,3 & 130,7 & 131,1 \\
\hline Pracowników & 100,0 & 112,1 & 119,0 & 123,7 & 127,1 & 132,3 & 132,7 \\
\hline Rolników & 100,0 & 112,8 & 115,8 & 123,1 & 119,7 & 127,9 & 127,6 \\
\hline $\begin{array}{c}\text { Pracujących na } \\
\text { własny rachunek }\end{array}$ & 100,0 & 109,1 & 110,4 & 110,3 & 111,7 & 117,2 & 117,8 \\
\hline $\begin{array}{c}\text { Emerytów i ren- } \\
\text { cistów }\end{array}$ & 100,0 & 110,3 & 118,2 & 122,8 & 127,3 & 132,9 & 134,9 \\
\hline
\end{tabular}

Źródło: opracowanie własne na podstawie danych GUS.

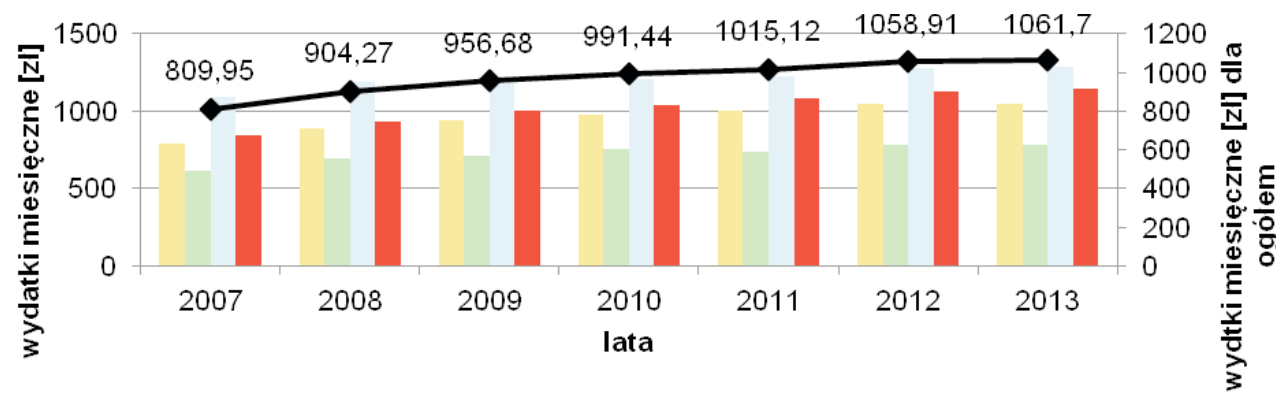

$\begin{array}{ll}\text { Pracowników } & \text { Rolników } \\ \text { Pracujących na wlasny rachunek } & \text { Emerytówi rencistów } \\ \sim \text { Ogólem } & \end{array}$

Wykres 2. Kształtowanie się miesięcznych wydatków polskich gospodarstw domowych w latach 2007-2013

Źródło: opracowanie własne na podstawie danych źródłowych GUS z badań budżetów gospodarstw domowych w Polsce w latach 2007-2013.

$\mathrm{Na}$ podstawie danych zawartych w powyższych tabelach oraz na wykresie 2 można zauważyć, że w badanym okresie polskie gospodarstwa domowe powiększyły swoje wydatki o $31,1 \%$. Wzrost ten podyktowany był przede wszystkim wzrostem cen bieżących. Największą dynamikę wydatków odnotowały gospodarstwa domowe emerytów i rencistów (wzrost o 34,9\%), najmniejszą natomiast - pracujących na własny rachunek (17,8\%). Mimo małej dynamiki zmian gospodarstwa domowe pracujących na własny rachunek wydawały więcej w porównaniu do danych wskazanych dla ogółu polskich gospodarstw w całym okresie objętym badaniem. 
Najniższe przeciętne miesięczne wydatki ponosiły gospodarstwa domowe rolników. Różnica w wydatkach na niekorzyść gospodarstw domowych rolników w porównaniu z gospodarstwami domowymi ogółem była odnotowywana w całym okresie analizy i wynosiła średnio 244 zł. W poszczególnych grupach odnotowano wzrost przeciętnych miesięcznych wydatków, jednak w badanym okresie największy wzrost przeciętnych miesięcznych wydatków odnotowały gospodarstwa domowe emerytów i rencistów.

Wzrost przeciętnych miesięcznych wydatków w badanym okresie spowodowany był przede wszystkim wzrostem cen części towarów, a także wzrostem wynagrodzeń przewyższających wzrost cen. W związku z tym towary oraz usługi dla znacznej części gospodarstw domowych stały się bardziej atrakcyjne.
Wysokość środków pieniężnych posiadanych przez gospodarstwa domowe kształtuje strukturę ich wydatków. Istotne informacje na temat kształtowania się struktury wydatków w zależności od osiąganych dochodów przedstawia prawo Engla. Zgodnie z tym prawem wzrost dochodów powoduje wzrost spożycia dóbr żywnościowych i nieżywnościowych, natomiast udział wydatków na artykuły żywnościowe maleje w ogóle wydatków konsumpcyjnych, gdyż tempo spożycia tych dóbr jest niższe w porównaniu ze spożyciem towarów nieżywnościowych. Malejący udział wydatków na żywność w całości wydatków konsumpcyjnych wskazuje na prawidłowe kształtowanie wydatków gospodarstw domowych (Włodarczyk-Śpiewak 2008: 162).

W tabeli 5 przedstawiono strukturę wydatków polskich gospodarstw domowych w latach 2007-2013.

Tabela 5. Struktura wydatków polskich gospodarstw domowych ogółem w latach 2007-2013 (wydatki ogółem = 100\%)

\begin{tabular}{|c|c|c|c|c|c|c|c|c|}
\hline \multirow{2}{*}{ Wyszczególnienie } & $\mathbf{2 0 0 7}$ & $\mathbf{2 0 0 8}$ & $\mathbf{2 0 0 9}$ & $\mathbf{2 0 1 0}$ & $\mathbf{2 0 1 1}$ & $\mathbf{2 0 1 2}$ & $\mathbf{2 0 1 3}$ \\
\cline { 2 - 9 } & \multicolumn{7}{|c|}{ w \% } \\
\hline $\begin{array}{c}\text { Żywność i napoje } \\
\text { bezalkoholowe }\end{array}$ & 26,60 & 25,60 & 25,10 & 24,83 & 25,03 & 24,92 & 24,90 \\
\hline $\begin{array}{c}\text { Napoje alkoholo- } \\
\text { we i wyroby tytoniowe }\end{array}$ & 2,70 & 2,60 & 2,72 & 2,72 & 2,70 & 2,69 & 2,57 \\
\hline Odzież i obuwie & 5,70 & 5,50 & 5,22 & 5,28 & 5,10 & 4,88 & 5,06 \\
\hline $\begin{array}{c}\text { Użytkowanie mieszka- } \\
\text { nia i nośniki energii }\end{array}$ & 18,4 & 18,9 & 19,65 & 20,16 & 20,72 & 20,19 & 20,77 \\
\hline $\begin{array}{c}\text { Wyposażenie mieszka- } \\
\text { nia i prowadzenie go- } \\
\text { spodarstwa domowego }\end{array}$ & 5,50 & 5,50 & 5,38 & 5,16 & 4,83 & 4,75 & 4,68 \\
\hline Zdrowie & 4,90 & 4,80 & 5,01 & 4,78 & 4,97 & 4,97 & 5,08 \\
\hline Transport & 9,30 & 10,10 & 9,69 & 9,56 & 9,56 & 9,72 & 9,64 \\
\hline tączność & 5,00 & 4,80 & 4,54 & 4,38 & 4,20 & 3,96 & 5,15 \\
\hline Rekreacja i kultura & 7,60 & 7,90 & 7,98 & 8,05 & 8,06 & 8,08 & 6,52 \\
\hline Edukacja & 1,40 & 1,20 & 1,20 & 1,29 & 1,23 & 1,17 & 1,18 \\
\hline Restauracje i hotele & 1,90 & 2,00 & 2,17 & 2,31 & 2,45 & 2,76 & 2,89 \\
\hline Inne towary i usługi & 5,30 & 5,20 & 5,26 & 5,21 & 5,15 & 5,89 & 5,77 \\
\hline Pozostałe wydatki & 4,20 & 4,30 & 4,47 & 4,60 & 4,26 & 4,30 & 4,16 \\
\hline
\end{tabular}


W badanym okresie zmieniła się struktura wydatków konsumpcyjnych gospodarstw domowych w Polsce. Ogólnie w strukturze wyróżnić można wydatki podstawowe oraz wydatki tzw. swobodnego wyboru. Do wydatków podstawowych zalicza się wydatki na żywność, odzież, obuwie, mieszkanie, energię elektryczną i cieplną, gaz, higienę i ochronę zdrowia. Wydatki na kulturę, oświatę, sport, wychowanie, turystykę i wypoczynek, transport i łączność określane są jako wydatki swobodnego wyboru (Kieżel 2004: 76), które zaspokajają potrzeby ponadpodstawowe. Udział procentowy wydatków podstawowych i wydatków swobodnego wyboru świadczyć może m.in. o poziomie zamożności gospodarstw domowych. Im wyższy udział dochodu przeznaczonego na wydatki swobodnego wyboru, tym wyższy poziom zamożności danego gospodarstwa domowego.

W 2007 roku procentowy udział wydatków na żywność i napoje bezalkoholowe w całości wydatków wynosił $26,6 \%$ i w ciągu badanego okresu miał tendencje malejącą (jedynie w 2011 roku nieznacznie wzróst, a w 2012 roku ponownie zmalał. Zatem można zakładać, że wskaźnik udziału wydatków na żywność w strukturze wszystkich wydatków polskich gospodarstw domowych ma tendencję malejącą, co jest zgodne z prawem Engla, a tym samym jest pozytywne dla działalności konsumentów. Malejącą tendencję w strukturze wydatków wykazują również wydatki na odzież i obuwie. Konieczność ponoszenia opłat stałych obniżyła zdolność gospodarstw domowych do nabywania innych dóbr i usług i wymusiła m.in. oszczędności czynione w przypadku zakupu odzieży i obuwia. Rosnący natomiast udział wydatków w całości wydatków konsumpcyjnych można zauważyć w przypadku wydatków na:

- użytkowanie mieszkania i nośniki energii (ich udział wzrósł z 18,4\% w 2007 roku do $20,77 \%$ w 2013 roku),

- rekreacja i kultura (należy zauważyć wzrost z 7,6\% w 2007 roku do $8,08 \%$ w 2012 roku, następnie spadek do 6,52\% w 2013 roku, jednakże można przyjąć, że ich udział w kolejnych latach nadal będzie wykazywać nieznaczny wzrost),

- restauracja i hotele (wzrost o ok. 1 punkt procentowy w 2013 roku w stosunku do 2007 roku).

Jeśli chodzi o udział wydatków na napoje alkoholowe i wyroby tytoniowe oraz wydatków na edukację, to w badanym okresie pozostawały one względnie stałe. Natomiast w przypadku wydatków na zdrowie i transport trudno mówić o jednoznacznych zmianach tych wielkości. W przypadku wydatków na zdrowie można zauważyć najpierw ich spadek, później wzrost i trudno jest tu mówić o jednoznacznym kierunku zmian. Podobne zjawisko występuje w przypadku wydatków na transport. Analizując strukturę wydatków polskich gospodarstw domowych ogółem, szczególną uwagę można zwrócić na:

- najwyższy, ale stopniowo malejący udział wydatków na żywność,

- duży udział wydatków związanych z utrzymaniem mieszkania,

- stosunkowo duży udział wydatków na transport,

- rosnący udział wydatków na rekreację i kulturę oraz restauracje i hotele,

- malejący udział wydatków na odzież i obuwie oraz łączność.

Ponadto można zauważyć spadek udziału wydatków na dobra podstawowe (przede wszystkim na żywność), stabilizowanie się udziału wydatków na dobra wyższego rzędu (przykładem mogą być wydatki na napoje alkoholowe i tytoń) oraz wzrost udziału wydatków na dobra luksusowe (tj. wydatków na rekreację i kulturę czy restauracje i hotele). Wpływ na takie kształtowanie się struktury wydatków 
miały niewątpliwie dochody gospodarstw domowych. Jedynie w roku 2013 można zauważyć pewne odchylenie od prawidłowości zmian struktury dochodów oraz wydatków polskich gospodarstw domowych. W tym przypadku należałoby przeprowadzić analizę za kolejne lata, by sprawdzić, jak kształtowały się dochody i wydatki opisanych grup społecznych.

Wpływ dochodów na poziom i strukturę wydatków konsumpcyjnych gospodarstw domowych

Zróżnicowanie przeciętnych miesięcznych dochodów oraz wydatków jest ściśle związane z określonymi uwarunkowaniami społeczno-ekonomiczno-demograficznymi poszczególnych gospodarstw domowych (Kowalska 2002: 13). Celem niniejszego artykułu jest wskazanie stopnia zależności wydatków konsumpcyjnych polskich gospodarstw domowych od poziomu osiąganych dochodów. Różne wzorce zachowań konsumentów mogą zależeć m.in. od fazy cyklu życia danego gospodarstwa domowego związanego z liczbą członków, wiekiem i wykształceniem rodziny, liczbą dzieci czy statusem cywilnym. W badaniach empirycznych wskazuje się też inne determinanty wydatków, np.: typ gospodarstwa domowego, miejsce zamieszkania czy inne czynniki socjoekonomiczne. Jednak, zgodnie z teorią ekonomii, podstawowym czynnikiem kształtującym poziom wydatków danego podmiotu jest dochód. Powszechnie wiadomo, że dochody gospodarstw domowych determinują ich wydatki na poszczególne dobra konsumpcyjne. Wysokość dochodów jest istotnym czynnikiem, który wpływa na zmianę wzorców konsumpcji. Wyniki te pokazują prawidłowość opisaną przez prawo Engla, która wskazuje, że w miarę poprawy sytuacji materialnej gospodarstwa domowego spada udział wydatków na żywność w wydatkach ogółem.

Od wysokości dochodów zależy nie tylko ilość nabywanych na rynku produktów, ale również struktura wydatków. Przy niskich dochodach gospodarstwa domowe przeznaczają praktycznie cały dochodów na zakup produktów, które zaspokoją ich najważniejsze potrzeby, tj. żywność, odzież, obuwie. Gospodarstwa domowe w miarę wzrostu dochodu zaczynają większą jego część przeznaczać na zakup dóbr i usług bardziej luksusowych. Trzeba jednak zaznaczyć, że nie każda zmiana dochodu będzie powodować natychmiastową zmianę poziomu i struktury wydatków. Bowiem każde gospodarstwo domowe ma swój własny ustalony schemat wydatków i wzrost dochodu nie prowadzi od razu do jego zmiany (Kieżel 2010: 153).

Według badań przeprowadzonych przez GUS w ostatnich latach nastąpiło duże zróżnicowanie przeciętnych miesięcznych dochodów i wydatków gospodarstw domowych. W roku 2013 udział wydatków w dochodzie rozporządzalnym stanowił $81,7 \%$ i był niższy o 0,5 pkt proc. niż w roku 2012, a o 5,5 pkt proc. w porównaniu z rokiem 2007 (wykres 3).

Zanotowano również dalszy spadek spożycia podstawowych artykułów żywnościowych. Nastąpiła poprawa wyposażenia polskich gospodarstw domowych w dobra trwałego użytkowania. Zróżnicowanie przeciętnych miesięcznych dochodów i wydatków między wskazanymi powyżej grupami społecznymi w 2013 roku było duże. Podobnie sytuacja wyglądała we wcześniejszych latach. W 2013 roku najwyższe przeciętne miesięczne dochody wykazywały gospodarstwa osób pracujących na własny rachunek (z wyłączeniem gospodarstw domowych rolników). Dochód w tej grupie był o 21,7\% wyższy od dochodu gospodarstw ogółem, a wydatki wyższe od przeciętnych wydatków ogółem. W ostatnim okresie 


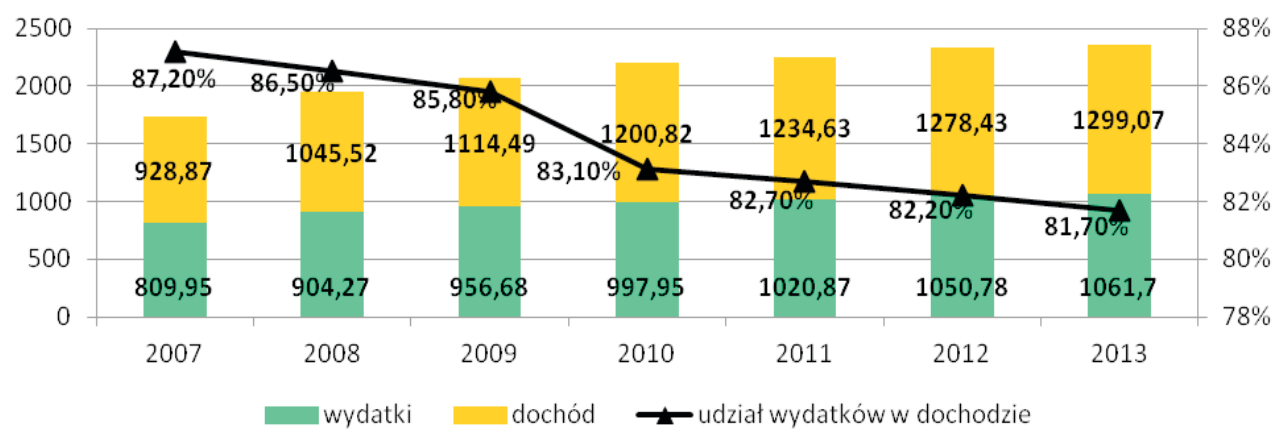

Wykres 3. Poziom przeciętnych miesięcznych dochodów i wydatków na osobę w gospodarstwie domowym oraz udział wydatków w dochodzie rozporządzalnym 2007-2011

Źródło: Sytuacja gospodarstw domowych w świetle wyników badań budżetów gospodarstw domowych, Warszawa, GUS. 2011, s. 1.

najwyższy udział wydatków w dochodach odnotowano $w$ gospodarstwach domowych rencistów $(93,9 \%)$, co może świadczyć o ograniczonych możliwościach do oszczędzania w tej grupie społecznej. W 2013 roku w większości grup społecznych wystąpił niewielki wzrost przeciętnych miesięcznych wydatków polskich gospodarstw domowych w stosunku do roku 2012. Jedynie w grupie gospodarstw domowych rolników wystąpił nieznaczny spadek wydatków w stosunku do roku poprzedniego (GUS 2011: 2-3). W pozostałych latach widać podobne zróżnicowanie $w$ przeciętnych miesięcznych dochodach i wydatkach polskich gospodarstw domowych. Zarówno w roku 2007, 2008 jak i 2009 najwyższe dochody osiągały gospodarstwa domowe pracujących na własny rachunek, zaś najniższe - gospodarstwa domowe emerytów i rencistów. Także badania przeprowadzone przez Ośrodek Badania Opinii Publicznej (OBOP) pokazują, że im wyższe dochody osiągają gospodarstwa domowe, tym większa część budżetu przeznaczana jest na przyjemność, naukę oraz na oszczędności. Natomiast wraz z pogorszeniem się sytuacji materialnej gospodarstwa domowego zwiększają się jego wydatki na zaspokojenie potrzeb pierwszego rzędu.

W niniejszej pracy w celu zbadania zależności między opisanymi zmiennymi wykorzystano ekonometryczny model zależności między wydatkami ogółem na dobra konsumpcyjne a dochodami gospodarstw domowych. W badaniu zastosowano współczynnik korelacji liniowej Pearsona, który jest miernikiem siły związku liniowego między dwiema cechami ilościowymi. Współczynnik ten bada, czy między dwoma cechami występuje korelacja. Dodatni znak współczynnika korelacji wskazuje na istnienie współzależności pozytywnej (dodatniej), ujemny natomiast oznacza współzależność negatywną (ujemną). Współczynnik może przyjmować wartości $<-1 ; 1>$, przy czym:

$r=0$ - brak korelacji, brak związku między cechami,

$r<0$ - korelacja ujemna, gdy wartość jednej cechy rośnie, to wartość drugiej cechy maleje,

$r>0$ - korelacja dodatnia, gdy wartość jednej cechy rośnie, to wartość drugiej cechy również rośnie i odwrotnie. Wzór na współczynnik korelacji Pearsona przedstawia się następująco: 
$r=\frac{n \times \sum x_{i} y_{i}-\sum x_{i} \times \sum y_{i}}{\sqrt{\left[n \times \sum x_{i}^{2}-\left(\sum x_{i}\right)^{2}\right] \times\left[n \times \sum y_{i}^{2}-\left(\sum y_{i}\right)^{2}\right]}}$

gdzie:

$x_{i}, y_{i}-i$-te wartości obserwacji z populacji $x$ i $y$,

$n$ - liczba obserwacji (Guzik, Jurek 2003: 51).

Wartość współczynnika korelacji liniowej Pearsona wynosi 0,996, co oznacza bardzo silną zależność między przeciętnymi miesięcznymi wydatkami a dochodami polskich gospodarstw domowych. Zależność ta jest statystycznie istotna na poziomie istotności wynoszącym 0,05. Oznacza to, że $w$ badanym okresie wraz ze wzrostem dochodów rośnie poziom wydatków gospodarstw domowych.

Na podstawie współczynnika korelacji liniowej Pearsona widać, że wysokość osiąganych dochodów wpływa na wielkość całkowitych wydatków konsumpcyjnych. Wraz ze wzrostem dochodów konsumentów rosną ich wydatki konsumpcyjne. Wzrost dochodu wpływa nie tylko na zwiększenie popytu na dobra i usługi, ale również może powodować zmianę struktury wydatków. Zmiana ta polega na zwiększeniu się w ogólnych wydatkach konsumentów wydatków na zakup dóbr wyższego rzędu, a zmniejszeniu się wydatków na dobra podstawowe.

\section{Podsumowanie}

Konsumpcja realizowana na poziomie gospodarstwa domowego zależy od wielu czynników działających zarówno w skali mikro-, jak i makroekonomicznej oraz zmienia się w czasie. Jednym z głównych czynników kształtujących zachowania konsumentów na rynku jest dochód. Mianowicie posiadanie dochodu przez gospodarstwo domowe jest warunkiem umożliwiającym zaspokojenie potrzeb całej rodziny. Wysokość dochodu wpływa bezpośrednio na wielkość całkowitych wydatków konsumpcyjnych. Podstawowa zależność między dochodami a wydatkami gospodarstw domowych jest taka, że im większe są dochody, tym większy popyt i odwrotnie. W miarę wzrostu dochodu gospodarstwo domowe zaczyna coraz większą jego część przeznaczać na zakup artykułów wyższego rzędu.

$\mathrm{Na}$ podstawie zaprezentowanych w artykule danych można stwierdzić, że w latach 2007-2013 wysokiej dynamice przeciętnych miesięcznych dochodów rozporządzalnych gospodarstw domowych w Polsce towarzyszył niższy poziom dynamiki przeciętnych miesięcznych wydatków (zarówno w odniesieniu do ogółu gospodarstw domowych, jak i do poszczególnych grup społeczno-zawodowych). Zauważalna jest również ogólna tendencja wzrostowa ogółu wydatków gospodarstw domowych. We wszystkich gospodarstwach występuje największy, ale malejący udział wydatków na żywność w strukturze wydatków. Na drugim miejscu znajdują się wydatki na użytkowanie mieszkania i nośniki energii, natomiast na trzecim - wydatki na transport. Inne cechy charakterystyczne dla struktury wydatków polskich gospodarstw domowych to rosnące wydatki na rekreację i kulturę oraz restauracje i hotele. Oprócz wydatków na żywność tendencję malejącą wykazywały również wydatki na odzież i obuwie oraz wydatki na łączność. Względnie na stałym poziomie pozostawały wydatki na edukację oraz na napoje alkoholowe i wyroby tytoniowe.

W badanym okresie najlepszą sytuację można zauważyć w gospodarstwach domowych pracujących na własny rachunek. Gospodarstwa te osiągały najwyższe zarówno wydatki, jak i dochody w porównaniu do innych grup społeczno-zawodowych. Względnie dobrą sytuację odnotować można zarówno w gospodarstwach domowych emerytów i rencistów. Najniższe wydatki 
oraz dochody zauważalne były w gospodarstwach domowych rolników. Na podstawie współczynnika korelacji liniowej Pearsona widać, że wysokość osiąganych dochodów wpływa na wielkość całkowitych wydatków konsumpcyjnych. Wraz ze wzrostem dochodów konsumentów rosną ich wydatki konsumpcyjne. Wzrost dochodu wpływa nie tylko na zwiększenie popytu na dobra i usługi, ale również może powodować zmianę struktury wydatków. Zmiana ta polega na zwiększeniu się w ogólnych wydatkach konsumentów

\section{Bibliografia}

Guzik B., Jurek W. (2003), Podstawowe metody ekonometrii, Poznań, UE.

Kowalska A. (2002), Zmiany struktury społeczno-ekonomicznej gospodarstw domowych i ich uwarunkowania, "Polityka społeczna", nr 4.

Kieżel E. (2004), Racjonalność konsumpcji i zachowań konsumentów, Warszawa, PWE.

Kieżel E. (2010), Konsument i jego zachowania na rynku europejskim, Warszawa, PWE.

Piekut M. (2008), Polskie gospodarstwa domowe - dochody, wydatki $i$ wyposażenie $w$ dobra trwałego użytkowania, Warszawa, SGGW.

Świecka B. (2008), Bankructwo gospodarstw domowych. Perspektywa ekonomiczna i społeczna, Warszawa, Difin.

Urban S., Szlachta K. (2005), Ekonomika i organizacja handlu żywnościq, Wrocław, AE.

Włodarczyk-Śpiewak K. (2007), Czynniki determinujqce strukturę konsumpcji młodych gospodarstw domowych, Szczecin, US. wydatków na zakup dóbr wyższego rzędu, a zmniejszeniu się wydatków na dobra podstawowe.

Przedstawione $\mathrm{w}$ artykule zmiany w strukturze dochodów oraz wydatków gospodarstw domowych w Polsce mogą być jednym z wielu czynników wpływających na kształtowanie się kondycji ekonomicznej członków tych gospodarstw. Czynniki te wraz z innymi determinantami mogą wyznaczać wzorce konsumpcji gospodarstw domowych nie tylko w Polsce, ale też w innych krajach.

Kopycińska D. (2005), Mikroekonomia, Szczecin, PTE.

Włodarczyk-Śpiewak K. (2008), Zmiany struktur wydatków gospodarstw domowych w Polsce, [w:] Konkurencyjność podmiotów rynkowych, red. D. Kopycińska, Szczecin, US.

Rocznik Statystyczny 2007, Warszawa, GUS.

Rocznik Statystyczny 2008, Warszawa, GUS.

Rocznik Statystyczny 2009, Warszawa, GUS.

Rocznik Statystyczny 2010, Warszawa, GUS.

Rocznik Statystyczny 2011, Warszawa, GUS.

Rocznik Statystyczny 2014, Warszawa, GUS.

Sytuacja gospodarstw domowych $w$ świetle wyników badań budżetów gospodarstw domowych, za lata 2007-2013, Warszawa, GUS. 
The level of income and the consumption of Polish households in 2007-2013 in the light of statistical surveys
Abstract
Thesis put forward stated that changes in the structure of spendings during the period of 2007-2013 were one of the many factors that had impact on the shape of financial condition of households. What is more, it had influ- ence on model consumption among people. All households were taken into consideration in the analysis. Data provided by General Statistical Office of Poland, papers "Household budgets" and "Condition of households in the light of household budgets research" were used to produce this paper. On that basis indicated that changes in structure of income and spendings in Poland are one of the many factors that have impact on financial condition of the members of households.

Keywords: household, spending, household budget, basic goods, price flexibility on demand, higher order goods, consumer 